\title{
Public Governance: The government of non-state actors in 'partnerships'
}

\author{
Karen Johnston
}

\begin{abstract}
The article focuses on public governance and attempts to disaggregate the complexities of state and non-state relations in partnerships. Partnerships, as a form of governance, involve state and non-state actors in networks which are increasingly being employed in the formulation and implementation of public policy. The involvement of state and non-state actors in partnerships and networks of co-governance and co-production of public services are evident throughout the United Kingdom (UK). This paper focuses on the internal dynamics of local partnerships and offers insights into the interactions between state and non-state actors in these governance networks. The paper concludes that state's authoritative role creates asymmetries in governance networks which make the theoretical conceptualisation of governance questionable.
\end{abstract}

Key Words: partnerships; governance; third sector; state and non state actors

\section{Introduction}

The past few decades has seen the integration of non-state actors in public service delivery with the introduction of neoliberal reforms of the state. Governance as a theoretical and taxonomical construct captured the relationship between state and non-state actors in the formulation of policy and delivery of public services. The concept of governance has gained traction over the years as an accepted construct and theory in public administration literature. This paper questions governance as a theory and taxonomy of state and non-state relations in the delivery of public services. It provides a critical perspective through empirical evidence and argues that the state, although a participant in networks, maintains a hegemonic role in governance networks.

The first section of the paper therefore provides a review of governance literature, but it is not the intension to provide a comprehensive review. This is beyond the scope this paper, rather we return to Rhodes' conceptualisation of governance since this is often cited and a pervasive basis for many theorisation and taxonomical analysis of governance. The paper then explores related and emerging concepts of governance, specifically public governance, co-governance, co-production and partnerships. These related conceptualisations too incorporate the ideation of state and non-state actors working within networks to formulate public policy and deliver public services.

The second section of the paper provides a brief overview of governance in the UK to contextualise the research. This section describes the various partnerships in local and health sectors in England, Scotland, Wales and Northern Ireland. The partnerships are configured in varied ways given reserved and devolved powers in the UK polity. Although it is acknowledged that there are variances, hence the inclusion of partnerships by locality in the research, the partnerships incorporate the ideation of governance since there are state and non-state actors involved in the public service delivery. 
The third section of the paper provides empirical evidence, based on a large scale, quantitative and qualitative survey, of the hegemonic role of the state in governance and public governance networks. Although there are a number of empirical studies on partnerships these tend to be case study based and limited to a sector and/or specific geographical localities (Durose et al, 2014). The research for this paper is significant since it makes a twofold contribution to governance scholarship. Firstly, the research involved sampling of more than one sector, i.e. local and health partnerships. Secondly, the research included England, Scotland, Wales and Northern Ireland in the sample and therefore not confined to one locality and/or polity.

The research is located at local and community levels as much of service delivery in the UK is delivered through these levels of governance (Wilson and Game, 2011). Furthermore, Rhodes provided three levels of analysis of governance; macro, meso and micro. This paper is concerned with the latter level of analysis, specifically public governance relationships within a local and community context to explore relations amongst actors and organisations close to the point of public service delivery.

The paper concludes that local level service delivery is taking place through an array of state and non-state networks, but that the conceptualisation of governance as networks being autonomous from the state is inaccurate. The research found that the state through its authoritative role in society employs non-state actors in networks to extend the authority of the state in the delivery of services. This paper argues that the authority of the state is not being 'hollowed out'.

\section{Governance: A Theoretical Concept}

Much has been written about governance and it has become a ubiquitous concept in public administration literature ${ }^{i}$. Governance has become a nebulous term, used in a variety of contexts and to some extent lost its meaning (see Bovaird, 2005). For the purposes of this paper we return to seminal and often cited work of Rhodes. He (1981:97-98; 2000:61; 2008:15) defined governance as: '...self-organising, inter-organisational networks characterised by interdependence, resource exchange, rules of the game based on trust and significant autonomy from the state'. Rhodes $(1996 ; 1997)$ argued that the authority of the state is being 'hollowed out' through this growing influence of self-organising networks and non-state actors involved in the formulation and implementation of public policy resulting in a differentiated polity. Rhodes (1981) in a study of British central-local relations developed a typology based on the theory of power dependence. He stated that:

(a) Any organisation is dependent upon other organisations for resources;

(b) In order to achieve goals, organisations have to exchange resources;

(c) Although decision making is constrained by other organisations, the dominant coalition retains some discretion with the dominant coalition influencing relationships which are seen as a problem and resources sought to address the problem;

(d) The dominant coalition employs strategies within known rules of the game to regulate the process of exchange; and

(e) Variations in the degree of discretion are a product of goals and the relative power potential of interacting organisations (Rhodes, 1981:98).

It is observable that public policy is being formulated and implemented through a plethora of formal and informal institutions, mechanisms and processes which in scholarly literature is referred to as governance (Sørensen and Torfing, 2005; Pierre and Peters, 2000). In the 
literature governance usually refers to public sector reforms involving privatisation, public enterprises, contracting-out, quasi markets, contract steering, local partnerships, etc. (Sørensen and Torfing, 2005). According to Sørensen and Torfing (2005) this often refers to a polity which is divided and fragmented into a variety of interdependent public, semi-public and private agencies

Rhodes $(2008 ; 2011)$ acknowledged that there are asymmetries of power within networks. He argues that networks are rooted in resource exchange and the distribution of resources between actors in a specific network remains central to any explanation of the distribution of power in that network (Rhodes, 2008:37). Sørensen and Torfing (2005: 203) also argue that there is an asymmetric allocation of material and immaterial resources amongst actors with some actors stronger and more central than others. However, they acknowledge that since participation in networks is voluntary and exit is always a possibility, and since the actors are depending on each other to 'get things done' no actor can command or force others in a hierarchical manner (ibid).

The concept of governance has seen a proliferation in the literature of related concepts such as public governance, co-governance and co-production. Public governance involves public resources and services provided by any permutation of government, private and civil society organisations such as the voluntary sector (Rhodes 1996; Pierre and Peters 2000). Public governance involves delivery of government services by private and third sector organisations with a need for collaboration and community engagement level (Kernaghan, 2009). It involves the exercise of power, authority and/or influence by a broad range of actors in joining up policies, services, structures, processes and systems in arrangements that extend across departmental, governmental and/or sector boundaries (Kernaghan, 2008). Important to public governance is networks of actors, integrating services and engaging the community at this micro-level (Kernaghan, 2009). Bovaird and Löffler (2003: 316) similarly describe public governance as '...the ways in which stakeholders interact with each other in order to influence the outcomes of public policies.'

Kooiman (2003) distinguished four co-modes of governance: (1) communicative governance (involving 'reasonable' citizens in service design and provision); (2) public-private partnerships; (3) co-management; and (3) networks (interaction amongst a variety of interests). The manifestation of collaborative public governance is some form of partnerships whose board or management committee is populated by the various interests (Skelcher, Mathur and Smith, 2005). Public governance therefore offers a mechanism of engaging relevant stakeholders and motivating joint action (ibid). Partnerships are semi-autonomous organisational vehicles through which governmental, private, voluntary and community sector actors engage in the process of debating, deliberating and delivering public policy at the regional and local level (Skelcher et al, 2005; Sullivan and Skelcher, 2002).

A related concept to governance and public governance is co-governance. Co-governance is public, private and civil society organisations involved in the planning and/or delivery of services (Brandsen and Pestoff, 2006). Moreover, co-governance is consensual regulation shared by public, civic and professional actions in the delivery of public services (Bode (2006). Voorberg, Bekkers and Tummers' (2013) study showed that co-governance involves co-creation and co-production which is defined as the active involvement of citizens in public service delivery by creating partnerships with the state. Furthermore, co-governance involves: (1) citizens as co-implementers of public policy; (2) citizens as co-designers; and (3) citizens as co-initiators (ibid). Ostrom (1996) defines co-production as a process through which inputs 
used to provide goods or services are contributed by individuals who are not from the same organisation. Co-production therefore refers to the mix of activities that public, private and societal actors contribute to the provision of public services (Pestoff and Brandsen, 2009). Bovaird (2007) argues that co-production is the provision of services through regular, long term relationships between professionalised providers from any sector and service users or other members of the community where all actors make substantial resource contributions. Co-production involves the 'seamless' and 'joined-up' provision of services where users and citizens play a key role in the definition and delivery of services (Bovaird, 2005). Thus, coproduction assumes that service users and communities can and often should be part of service planning and delivery (Bovaird, 2007).

Skelcher et al's (2005) review of previous co-governance research found that partnerships operate in an uncertain and ill-defined authority and accountability environment, accentuating the problems arising from hollowing-out which erodes accountability and obscures who is accountable for what (ibid). This is partly because partnerships are designed to integrate horizontal and vertical policy implementation rather than democratic needs (ibid). Bovaird (2005) found that there are 'trade-offs' in public governance arrangements: more stakeholder engagement may give rise to higher costs and sometimes delays in decision making and implementation; fragmentation of accountability; and the regulation of stakeholder power may erode trust (ibid).

Governance is a contested concept both in theory and practice (Bovaird, 2005). Davies (2011) criticised the governance thesis and argued that new structures of local governance were essentially orchestrated by central government's delivery agenda. Similarly, Holliday (2000) argues that central government was increasing its authority as evidenced by its increased size, key role in policy networks and retaining its coordination capacity in centrallocal relations. Bell and Hindmoor (2009) also contest the thesis of governance and argue that government and hierarchical rules are not being replaced by governance arrangements through markets, interest group associations and community engagement, but rather the role of government is being supplemented. Fenwick, Johnston Miller and McTavish (2012) similarly argue that government's authority is not being eroded but extended through bureaucracy and integration of non-state actors through bureaucratic arrangements.

The concepts of governance, public governance, co-governance and co-production are often used interchangeably (Voorberg, Bekkers and Tummers, 2013). The recurring and taxonomical issue of governance is that it involves trust, interdependence, autonomy from the state, shared purpose and exchange of resources amongst actors in a network. The review of literature for this paper provided a number of critical research questions. To what extent does trust exist between state and non-state actors; how interdependent and autonomous are actors; do actors have a shared purpose and is there an exchange of resources in governance networks? These questions informed the research and were operationalized for the research survey.

As stated above, partnerships are increasingly being employed in delivery of public services. Thus, in the next section we first turn our attention to partnerships in the UK polity and the location of the research.

\section{Public Governance in England, Scotland, Wales and Northern Ireland}

In England, Local Enterprise Partnerships were established with the introduction of the 2010 White Paper 'Local Growth: Realising Every Place's Potential'. The aim was to: shift power 
to local communities and business, enabling places to tailor their approach to local circumstances; and support investment in places and people to tackle the barriers to growth (Department of Business, Innovation and Skills, 2010:5). By 2013, 39 local enterprise partnerships were established involving local government, business and community stakeholders accessing £370million funding (Department of Communities and Local Government, 2014). Within the health sector in England, health and well-being boards were established after the introduction of the Health and Social Care Act of 2012. The aim was to integrate health and social care through local authorities in co-governance with the NHS, social care, children's services and elected representatives from Healthwatch to meet the needs of the local population, address local inequalities in health and enhance accountability to the local community (see Health and Social Care Act 2012). There are currently 153 health and well-being boards in England.

In Wales public governance is articulated in the Welsh Government's policy document, 'Shared Purpose - Shared Delivery' (2012). This saw an integration of public services with local service boards, non-statutory partnerships, being established across the 22 Welsh local authority areas. The boards ensured joined-up service delivery with local government working across organizational boundaries, pooling capacity and expertise and tackling structural blockages in the system of public service delivery (Welsh Local Government Association, 2014). Although there is variance in size, structure and membership of local service boards, generally they consist of elected officials and chief executives of local government, relevant public sector and community leaders. There was also a re-design of health services with 'One Wales'. The aim of the policy was to improve health outcomes and ensure that the Welsh NHS delivered care effectively with partnership arrangements (NHS Wales, 2014). Community health councils, statutory lay bodies, represent the interests of the public in the health service in their district in the form of partnerships (ibid). This allows for inclusion of community, private and public sector stakeholders in the determination of local services.

In Scotland at local government level there are community planning partnerships and within the health sector there are community health and care partnerships. Community planning partnerships were established in 2003 as part of the statutory requirements of the Local Government Act. The act stipulates that 'Community Planning is ... a process ... whereby public services in the area of the local authority are planned and provided after consultation and on-going co-operation ... among all public bodies ... and with community bodies' (Scottish Government, 2003). The aim of the partnerships is to ensure that: people and communities are engaged in the decisions made by public services which affect them; and organisations work together in partnership to provide better public services (ibid). There are 32 community planning partnerships commensurate with local authorities and include a range of public sector stakeholders such as the NHS, police, education, welfare services as well as business, voluntary and community representatives. Public governance in the health sector in Scotland can be traced to the Community Health Partnerships Regulations of 2004. Following some criticisms by Audit Scotland in 2011 concerning the lack of partnership and joined-up health service delivery, community health and care partnerships were established. The partnerships allow for better integration of service delivery across NHS Scotland with other public sector bodies such as local government. In addition to a statutory representation of local government on NHS health boards, the partnerships involve local authority, voluntary and community representation. In Scotland it should be noted that single outcome agreements entrench public governance as it involves partnerships of statutory and nonstatutory bodies focused on achieving local service delivery needs and outcomes. 
Northern Ireland too has some form of public governance in local commissioning groups, but at the time of writing local government was undergoing reform and restructuring. As yet it did not have any statutory partnerships at local government level. Within the health sector local commissioning groups are responsible for the commissioning of health and social care by addressing the care needs of their local population; responsible for assessing health and social care needs; planning health and social care to meet current and emerging needs; and securing the delivery of health and social care to meet assessed needs (Health and Social Care Northern Ireland, 2014). The local commissioning groups' memberships consist of local government representatives, public health officials, medical and clinical practitioners, voluntary sector and community stakeholders.

Public governance is evident throughout the UK and although there are variances in size, composition and statutory obligation; there are similarities and comparabilities. The public governance arrangements across the UK involve states and non-state actors involved in the design and delivery of public services. The aim is often to integrate and join-up service delivery providing a platform for the voluntary sector and community stakeholders to cogovern services. This paper therefore investigates the aforementioned partnerships to address the taxonomical issues and research questions to better understand the interaction between state and non-state actor in public governance.

\section{Research Method and Data}

The research involved an online survey disseminated to local government and health partnerships throughout the UK. The survey was designed based on the review of literature and extant public governance research. In England the survey was disseminated to local enterprise partnerships, and health and wellbeing boards; in Scotland to community planning partnerships, and community health and care partnerships; in Wales to local service boards, and community health councils; and in Northern Ireland to local commissioning groups as partnerships within the health and care boards. The surveys were sent to the chairs or secretariats of the partnerships. In total there were 290 local government and health partnerships in the UK, 270 randomly sampled and 152 responses received. The disaggregation of the population and sample partnerships per sector and region is illustrated in Table 1. The survey included profile questions (e.g. sector and region); questions on trust, interdependence, autonomy, shared purpose, and exchange of resources according to a Likert scale and a final open-ended question ${ }^{\text {ii }}$. The most significant findings are provided in the next section. ${ }^{\text {iii }}$

Table 1: Population and Sample of Partnerships

\begin{tabular}{llllll}
\hline Region & $\begin{array}{c}\text { Local } \\
\text { Government } \\
(\mathbf{N})\end{array}$ & $\begin{array}{c}\text { Local } \\
\text { Government } \\
(\mathbf{n})\end{array}$ & $\begin{array}{c}\text { Health } \\
(\mathbf{N})\end{array}$ & $\begin{array}{c}\text { Health } \\
(\mathbf{n})\end{array}$ \\
\hline Scotland & 32 & & 28 & 31 & 31 \\
England & 39 & 38 & 153 & 140 \\
Wales & 22 & 20 & 8 & 8 \\
N. Ireland & - & - & 5 & 5 \\
\hline Total & 93 & & 86 & 197 & 184 \\
\hline
\end{tabular}

Findings 
Most of the respondents were male (58\%); within older age categories and were highly qualified. The majority of respondents $(64.5 \%)$ regarded their primary employment within the public sector.

Most respondents were in agreement that their partnership was effective. Respondents agreed $(35.5 \%)$ or were neutral $(26.3 \%)$ as to whether partnerships were time-consuming in the process of decision making. Yet, when asked whether partnerships were efficient since it saved time involving stakeholders from the start of the decision making process, 5.9\% strongly agreed; $34.9 \%$ agreed; $25.7 \%$ remained neutral; $5.3 \%$ strongly disagreed and $8.6 \%$ disagreed. Most respondents agreed (40\% agreed and $7.2 \%$ strongly agreed) that the partnership makes a real difference in improving services in the community.

On questions of trust most respondents agreed that there were high levels of trust among partnership stakeholders. However, a disaggregation of data by sector reveals a more complex picture with non-state actors less in agreement (see Table 2). Respondents also agreed that they felt free to share information and express their opinion with stakeholders in the partnership. On further measures of trust there was general agreement that partnerships allow for the development of network relationships and social capital. For the most part respondents agreed that they trusted partners to deliver on decisions made by the forum. Yet on questions of accountability and trust, the responses were mixed. For example, respondents were asked whether partners in the forum held each other to account for performance. The responses ranged from: $7 \%$ strongly disagreed; $19.7 \%$ disagreed; $26.3 \%$ remained neutral; $32.2 \%$ agreed and $3.9 \%$ strongly agreed.

Table 2: Levels of Trust

\begin{tabular}{lccccc}
\hline Sector & $\begin{array}{c}\text { Strongly } \\
\text { Disagree }\end{array}$ & Disagree & Neutral & Agree & $\begin{array}{c}\text { Strongly } \\
\text { Agree }\end{array}$ \\
\hline Public & $2 \%$ & $7.1 \%$ & $26.5 \%$ & $38.8 \%$ & $7.1 \%$ \\
Private & $0 \%$ & $18.2 \%$ & $0 \%$ & $63.6 \%$ & $18.2 \%$ \\
Voluntary & $0 \%$ & $21.4 \%$ & $28.6 \%$ & $35.7 \%$ & $0 \%$ \\
\hline
\end{tabular}

Questions relating to the extent to which there was an exchange of resources showed that overall there was tendency towards agreement, but a disaggregation of data by sector revealed that respondents from the voluntary sector were in less agreement (see Table 3). Most respondents largely agreed that government used partnership forums as a means to gain information of service delivery needs in communities. Similarly, most respondents strongly agreed $(22.4 \%)$ and agreed $(49.3 \%)$ that partnerships provided a forum for diverse stakeholder views to be taken into account. Yet, there were mixed responses to questions on the extent to which there was community participation. For example, when asked whether the partnership had a high level of citizen engagement and participation, the respondents tended to disagree. Furthermore, most respondents disagreed that there was a community awareness of the benefits delivered by the partnership forum. Although, respondents agreed that the partnership forum allowed them a better understanding of ways in which to improve policy and service delivery.

Table 3: Exchange of Resources

\begin{tabular}{lccccc}
\hline Sector & $\begin{array}{c}\text { Strongly } \\
\text { Disagree }\end{array}$ & Disagree & Neutral & Agree & $\begin{array}{c}\text { Strongly } \\
\text { Agree }\end{array}$ \\
\hline Public & $3.1 \%$ & $14.3 \%$ & $29.6 \%$ & $26.5 \%$ & $7.1 \%$
\end{tabular}




\begin{tabular}{lccccc} 
Private & $0 \%$ & $0 \%$ & $36.4 \%$ & $54.5 \%$ & $9.1 \%$ \\
Voluntary & $0 \%$ & $35.7 \%$ & $21.4 \%$ & $28.6 \%$ & $0 \%$ \\
\hline
\end{tabular}

Non-state actors mostly agreed that government played a dominant role in partnerships. Most respondents tended to agree that government was using partnership stakeholder resources to achieve its objectives (see Table 4). Respondents tended to agree that if the partnership fails to deliver services there is a high risk to users. Thus, on questions of shared purpose there was general agreement that there was collective decision making in the forum; that respective stakeholder knowledge and expertise was taken on board when changing or re-designing services; that stakeholder views shape the policy agenda and change; and that stakeholders try to make decisions which benefit the community in general. Thus, respondents disagreed that forums were merely talk-shops but that there was a shared purpose of improving services for the community. Most respondents, even non-state actors, that the non-governmental stakeholders use the forum to advocate their interests.

Table 4: The Public Sector is increasingly using stakeholder resources to achieve their objectives

\begin{tabular}{lccccc}
\hline Sector & $\begin{array}{c}\text { Strongly } \\
\text { Disagree }\end{array}$ & Disagree & Neutral & Agree & $\begin{array}{c}\text { Strongly } \\
\text { Agree }\end{array}$ \\
\hline Public & $2 \%$ & $10.2 \%$ & $18.4 \%$ & $45.9 \%$ & $4.1 \%$ \\
Private & $0 \%$ & $9.1 \%$ & $27.3 \%$ & $36.4 \%$ & $18.2 \%$ \\
Voluntary & $0 \%$ & $0 \%$ & $14.3 \%$ & $42.9 \%$ & $14.3 \%$ \\
\hline
\end{tabular}

On measures of autonomy most respondents agreed that they were accountable to their respective organisations. Similarly, most respondents agreed that they often had to account for their performance to the organisation which they represented in the forum; and that the performance of the partnership is monitored by government. Furthermore, most respondents disagreed that the partnership was independent and autonomous from government. Moreover, respondents agreed that the voluntary sector is becoming part of government in delivering services (see Table 5).

Table 5: The voluntary sector is becoming part of government in delivering services

\begin{tabular}{lccccc}
\hline Sector & $\begin{array}{c}\text { Strongly } \\
\text { Disagree }\end{array}$ & Disagree & Neutral & Agree & $\begin{array}{c}\text { Strongly } \\
\text { Agree }\end{array}$ \\
\hline Public & $1 \%$ & $15.3 \%$ & $17.3 \%$ & $41.8 \%$ & $5.1 \%$ \\
Private & $0 \%$ & $9.1 \%$ & $36.4 \%$ & $36.4 \%$ & $9.1 \%$ \\
Voluntary & $7.1 \%$ & $7.1 \%$ & $14.3 \%$ & $21.4 \%$ & $2.1 .4 \%$ \\
\hline
\end{tabular}

\section{Discussion}

The study showed that although most respondents viewed partnerships as an effective forum for decision making, they considered it a time-consuming process. This finding is consistent with Bovaird's (2005) study of trade-offs in public governance where the opportunity cost in terms of decision making time is balanced with the inclusion of diverse stakeholder views making for more informed decisions. The research also supports Bovaird's (2007) view that co-governance and co-production involve relationships between professional providers. The research demonstrated that although partnerships involve a network of public, private and voluntary actors, the majority are from a professional class. Thus, partnerships allow for 
network opportunities and the building of social capital between a professional class of public service providers.

Most respondents agreed that trust exists within their partnerships. However, caution should be exercised in the interpretation of the findings with regards to trust. The majority of respondents were from the public sector and indeed much of partnership forums tend to consist of public sector members. This would allow for inter-agency collaboration which may explain the findings of trust, but as the disaggregation of data by sector shows, voluntary sector respondents are less in agreement that trust exists. This finding supports the argument of the asymmetries of power where government tends to dominate partnerships (see Rhodes, 2008; Holliday, 2000; Davies, 2011). The majority of qualitative comments in the survey by voluntary sector respondents refer to the dominance of governance and asymmetrical power relations as the following quotes illustrate:

My inclusion, representing voluntary groups ... I feel is paying lip service to 'community involvement'. The forum is run by professionals with their interests in mind and my inclusion ticks a box which satisfies government.

The Partnership Forum of which I'm a member, although has all stakeholders as equal partners, it's still clear that everything is geared towards Council Officers and Politicians; Community reps often feel their presence is tokenistic due to lack of knowledge of topics covered, lack of knowledge of processes involved - Community reps usually have limited knowledge of council, government processes due to being from outside the 'professional' organisations involved.

Thus, to address the research question of whether trust exists; trust is evident between the professional class of state actors in partnerships, but there is less evident between state and non-state actors in partnerships.

The findings on the extent of resource exchange at first appear inconclusive but while there appears a free exchange of information, there appears to be less exchange of financial resources. The latter may be a result of less devolved budgeting to partnerships and less interagency financial exchange to affect outcomes. This is partly explained by the prevalence of bureaucratic financial and performance frameworks which often create organisational silos despite the existence of partnerships. Thus, while there is an exchange of information, shared decision making and purpose to affect joined-up policy objectives, there is less organisational integration and interdependence through financial resource exchange. Furthermore, there appears to be a bottom-up exchange of information with forums providing an opportunity for stakeholders to inform the policy process of community needs. However, there does not appear to be a great deal of community participation and awareness of partnerships. Arguably, genuine bottom-up democratic and community engagement is limited, but the forum does allow for, to some extent, stakeholder inputs which inform policy and cogovernance decision making. However, accountability is to respective organisations. The research question on the extent of exchange of resources shows that there is indeed an exchange, but that this is limited to information exchange to inform decision making. A few comments can be made about the interdependence amongst stakeholders in the forum. There is a perception by non-state actors that the state actors dominate forums and that there tends to be an agreement that the state sector are using stakeholder resources to achieve policy objectives. Yet, there does appear to be a shared purpose of improving service delivery within the community and that partnership forums provide a platform for diverse views to be taken 
on board - sometimes affording non-state actors with an opportunity at community level to inform the policy agenda and affect service delivery. Thus, it appears that state and non-state actors do have a shared purpose of a public service ethos. Yet interdependence to achieve this shared purpose is limited.

There does not appear to be high levels of autonomy of partnership forums. Thus, state and non-state actors in networks are not autonomous from the state. Indeed there was a general consensus that the performance of partnerships was monitored by the state; that there were lines of accountability to respective organisations rather than to the partnership; and that the state was using non-state actors and their resources in the delivery of services with most respondents agreeing that non-state actors were becoming part of the state delivery nexus.

\section{Conclusion}

The research demonstrated that there is limited trust between state and non-state actors; limited interdependence and exchange of resources between the actors; and state and nonstate actors in networks are not autonomous from the state. However, the exception is that there is shared purpose between stakeholders in these partnerships, principally concerning improving public service delivery. Although, public governance does involve a network of state and non-state actors, there are asymmetries of power. The state maintains its dominant role through its financial and regulatory authority. Thus, the state's hegemony and dominance in public governance has not been eroded or 'hollowed-out'. Indeed scholars such as Holliday (2000) and Davies (2011) have observed that state actors are becoming an extension of the state. Fenwick et al (2012) for example argue that non-state actors in 'partnerships' are becoming part of a meta-bureaucracy. Many respondents acknowledged a lack of autonomy from the state and the assimilation of non-state organisations into state bureaucracy through financial and performance accountabilities. Thus, there does appear to be some hierarchical accountability to respective organisations, and depending on the extent of regulation and performance management, non-state actors may also be accountable to the state through the partnership.

The research offers insights into public governance by analysing local and health public governance in the UK and argues that the governance thesis is questionable. The state remains the authoritative actor in the allocation of resources and agenda-setting. What public governance does offer is to afford non-state actors the opportunity to inform the state, as the authoritative sector, on public service delivery needs. Yet, community participation and bottom-up democracy is limited and restricted to professional representatives of the community.

Public governance is arguably a site for improving joined-up service delivery and public policy but this depends on the state's receptivity and capacity to relinquish its hegemonic role. This is unlikely given financial and performance accountabilities and the politics of public services. It is more likely that public services will continue along the trajectory of neoliberal ideas of the role of the state with public governance involving the non-state sector contracted-in or steered to deliver public policy and service delivery objectives. Thus, interpreting the taxonomy of state and non-state relations in the UK, it would be more accurate to refer to this as government than governance.

\section{References}


Bell, S. and Hindmoor, A. (2009) 'The Governance of Public Affairs', Journal of Public Affairs, 9: 149-159.

Bevir, M., and R. A. W. Rhodes (2003) Interpreting British governance, London: Routledge

Bevir, M. and Rhodes, R.A.W. (2006) Governance Stories, London: Routledge.

Bode, I. (2006) 'Co-Governance within Networks and the Non-Profit-For-Profit Divide: A cross cultural perspective on the evolution of domiciliary elderly care', Public Management Review, 8 (4): 551-566.

Bovaird, T. (2005) 'Public governance: balancing stakeholder power in a network society', International Review of Administrative Sciences, 71 (2): 217-228

Bovaird, T. (2007) 'Beyond Engagement and Participation: User and Community Coproduction of Public Services', Public Administration Review, 67 (5): 846-858.

Bovaird, T. and Loffler, E. (2003) 'Evaluating the Quality of Public Governance: Indicators, Models and Methodologies', International Review of Administrative Sciences, 69 (3): 313328.

Brandsen, T. and Pestoff, V. (2006) 'Co-production the Third Sector and Delivery of Public Services', Public Management Review, 8 (4): 493-501.

Davies, J.S. (2011) Challenging Governance Theory: From Networks to Hegemony, Bristol: The Policy Press.

Department of Business, Innovation and Skills (2010) Local Growth: Realising Every Place's Potential, https://www.gov.uk/government/uploads/system/uploads/attachment_data/file/32076/cm7 961-local-growth-white-paper.pdf, accessed February 2014.

Department of Communities and Local Government (2014) 'Supporting Economic Growth Through Local Enterprise Partnerships and Enterprise Zones, https://www.gov.uk/government/policies/supporting-economic-growth-through-localenterprise-partnerships-and-enterprise-zones, accessed February 2014.

Durose, C., Mangan, C., Needham, C. and Rees, J. (2014) 'Evaluating co-production: pragmatic approaches to building the evidence base', Political Studies Association Annual Conference, 2014, Manchester.

Fenwick, J., Miller Johnston, K. and McTavish, D. (2012) 'Co-governance or Metabureaucracy? Perspectives of local governance "partnerships" in England and Scotland', Policy \& Politics, 40 (3), pp. 405-422.

Health and Social Care Northern Ireland (2014) Involving You, http://www.hscni.net/index.php?link=involve, accessed February 2014.

Holliday, I. (2000) 'Is the British state hollowing out?' Political Quarterly, 71 (2): 141-263.

Jessop, B. (2003) 'The Dynamics of Partnership and Governance Failure' in H.P. Bang (ed.) Governance as Social and Political Communication, Manchester: Manchester University Press.

Jessop, B. (2004) 'Multi-level Governance and Multi-level Meta-Governance' in I. Bache and M. Flinders (eds.) Multi-Level Governance, Oxford: Oxford University Press.

Kernaghan, K. (2008) Integrating Service Delivery: Barriers and Benchmarks, Toronto: Institute of Citizen-Centred Service.

Kernaghan, K. (2009) 'Moving towards integrated public governance: improving service delivery through community engagement,' International Review of Administrative Sciences, 75 (2): 239-254.

Kettl, D. F. (2002) The Transformation of Governance: Public administration for the twentyfirst century America, Baltimore: Johns Hopkins University Press.

Kooiman, J. (2003) Governing as Governance, London: Sage.

Koppenjan and Klijn (2004)

March, J.G. and Olsen, J.P. (1995) Democratic Governance, New York: Free Press. 
Marcussen, M. and Torfing, J. (eds.) Democratic Network Governance in Europe, Basingstoke: Palgrave-Macmillan.

NHS Wales (2014) Health in Wales, https://www.wales.nhs.uk/nhswalesaboutus/structure, accessed February 2014.

Ostrom, E. (1996) 'Crossing the Great Divide: Co-production, Synergy and Development', World Development, 24 (6): 1073-1087.

Pierre, J. and Peters, B.G. (2000) Governance, Politics and the State, Basingstoke: Macmillan.

Rhodes, R. A. W. (1981) Control and power in central-local government relationships, Aldershot: Ashgate.

Rhodes, R. A. W (1996) 'The New Governance: Governing without Government', Political Studies, 44 (4): 652-667.

Rhodes, R. A. W. (1997) Understanding governance, Buckingham and Philadelphia: Open University Press.

Rhodes, R.A.W. (2000) 'Governance in Public Administration' in J. Pierre (ed.) Debating Governance: Authority, Steering and Democracy, Oxford: Oxford University Press.

Rhodes, R.A.W. (2008) Understanding Governance: Policy Networks, Governance, Reflexivity and Accountability, Maidenhead: Open University Press.

Rhodes, R.A.W. (2011) 'The Governance Narrative: Key Findings and Lessons from the ESRC's Whitehall Programme'in R.A.W. Rhodes (ed.) Public Administration 25 years of analysis and debate, Chichester: John Wiley \& Sons.

Scottish Government (2003) Local Government Act, http://www.legislation.gov.uk/asp/2003/1/contents, accessed February 2014.

Skelcher, C., Mathur, N. and Smith, M. (2005) 'The Public Governance of Collaborative Spaces: Discourse, Design and Democracy’, Public Administration, 83 (3): 573-596.

Sørensen, E. and Torfing, J. (2005) 'Network Governance and Post-Liberal Democracy' Administrative Theory \& Praxis, 27 (2): 197-237.

Stoker, G. (2000) 'Urban Political Science and the Challenge of Urban Governance', in J. Pierre (ed.), Debating Governance: Authority Steering and Democracy, Oxford: Oxford University Press.

Sullivan, H. and Skelcher, C. (2002) Working Across Boundaries: Collaboration in Public Services, Basingstoke: Palgrave.

Voorberg, W., Bekkers, V. and Tummers, L. (2013) 'Co-creation and Co-production in Social Innovation: A Systematic Review and Future Research Agenda', EGPA Annual Conference, 11 - 13 September 2013, Edinburgh.

Welsh Local Government Association (2014) Local Service Boards, http://www.wlga.gov.uk/local-service-boards, accessed February 2014.

Welsh Government (2012) Shared Purpose - Shared Delivery, http://wales.gov.uk/docs/dpsp/publications/130205sharedpurpdeliveryv2en.pdf, accessed February 2014.

Wilson, D. and Game, C. (2011) Local Government in the UK, Basingstoke: Palgrave Macmillan

\footnotetext{
' See March and Olsen (1995), Rhodes (1997), Stoker (2000), Jessop (2003; 2004), Kettl (2002), Bevir and Rhodes, 2003; 2006), Koppenjan and Klijn (2004), Sørensen and Torfing (2005), Marcussen and Torfing (2007).

ii The survey is available from the corresponding author upon request.

iii It is beyond the word limit of the paper to present all the findings of the research such as disaggregated analysis by locality, responses of local government vis-à-vis health sector, and responses by characteristics. The paper provides findings to address the research questions and hypotheses.
} 